British universities

\section{Better management demanded}

BRITISH universities are in for another shake-up, this time a revolution engendered from within. So much is clear from the report published earlier this week of the committee under Sir Alex Jarrett set up a year ago to give the Committee of ViceChancellors and Principals advice on the effective management of universities.

The study now completed has been an unusual exercise, in which individual academics collaborated with professional management consultants and firms of auditors to look into the efficiency of six institutions (the universities of Edinburgh, Essex, Loughborough, Nottingham, Sheffield and University College, London). The report now published is that of the steering committee for the separate studies, and seeks to emphasize some general conclusions reached.

The report seems to accept that the financial deprivation of the British university system will continue, and perhaps even intensify. The committee notes that the hope that the severe cuts of 1981 (effectively a reduction of budgets by 17 per cent over three years) have not been followed by the once-promised "level funding" but by a period during which central government support for universities has been fixed in cash terms that do not adequately compensate for inflation.

The committee notes that, during this period, the British government has also taken steps to influence the pattern of university development, both by the encouragements of some kinds of academic developments and by limitations of student numbers. The report pleads that, in the interests of efficiency, the government should make clear its intentions towards the British university system and that it should look for some way of enabling universities to plan more than one year ahead. Specifically, the committee asks that the government should be prepared to meet the "whole or the greater part" of the cost of such academic redundancy as may be needed in the future.

Starting from the view that change within universities will be further stimulated by the determination of the University Grants Committee to distribute funds more selectively in future, the committee argues for more decisive management within universities. It says that governing bodies (variously called "councils" and "courts" in the British system) should assume responsibility for strategic planning and that vice-chancellors (also called principals) should be recognized as the chief executives as well as academic leaders of institutions (and be given increased powers to do so when necessary).

Ordinarily, the Jarrett report says, there should be a joint committee of the council and the academic senate, with the vicechancellor as chairman, to superintend planning and the allocation of resources within a university. At the department level, the report says, steps should be taken to see that the performance of individual academics, as teachers and in research, is regularly assessed. In general, the report asks that universities should prune the numbers of committees dealing with other than academic matters, delegating affairs such as the operation of student residences
Japanese whaling
Tokyo

UNSUSPECTING foreigners out in Roppongi, the nightlife centre of Tokyo, are in for a surprise, for there amongst the flashing neon is a large sign in English, paid for by the All Japan Seaman's Union, reading "Continue the whaling on scientific facts". These words, designed to strike at the heart of logically minded Westerners, may be the last from a dying industry.

Scientific facts or no scientific facts, decisions are rapidly being made about the future of whaling in Japan and, despite last-ditch diplomatic efforts by Japan's Fishery Agency, concessions are having to be made that almost certainly spell doom for the offshore whaling industry.

In December last year, the Japanese government filed a formal objection to the 1984-85 International Whaling Commission (IWC) quota for the minke whale catch in the Antarctic Ocean - minke whaling forming the backbone of the Japanese whaling industry. The IWC quota had been set at 4,224 head, 37 per cent down from the previous year, of which 1,941 head were allocated to Japan. By filing the objection, Japan freed itself from the need to observe any quota at all; soon after, however, Japan announced it would "voluntarily" limit Antarctic minke whaling in the November 1984/March 1985 whaling season to the previous season's levels $(3,027$ head). This, however, did not appease world opinion sufficiently for the United States to withdraw its threat to invoke the Packwood-Magnusson Amendment, a domestic ruling to cut the fishery catch in US waters of any country that defied IWC quotas. This would mean that Japan's huge fishing quota in the US 200-mile fishing zone would be halved in the first year of defiance and reduced to nothing in the second. To buy time for talks, a further compromise was made: the Japanese Antarctic whaling fleet was ordered to stop catching on reaching the new quota set by IWC and return home.

But the move did little to ease US pressure, and a series of talks between the United States and Japan has led to an ultimatum that Japan must withdraw an objection it filed earlier to the IWC complete ban and the maintainance of buildings to university officials.

The report also asks that the grants committee should itself be more active and articulate, and that it should be more vigilant in monitoring promises made by individual universities (as when, in 1981, universities agreed to close some departments and to run others in collaboration with neighbouring institutions). The Jarrett report also says there should be a review of the grants committee itself, in part so as to tell whether it is sufficiently well-provided with resources for the work it has to do.

\title{
Hollow victory for United States?
}

on commercial whaling that is to begin in 1986. Withdrawal of the objection would effectively mean complete defeat: all Japanese commercial whaling would have to end by 1988. All that the Japanese have so far won from the United States is an extra two years' grace - 1988 rather than 1986 - before they must observe the moratorium. Even this gesture was hotly contested in the courts by US environmentalists. A last-minute attempt to gain further concessions from the United States is under way this week, but the Japanese government has already admitted that little can be expected.

The implication of the Seaman's Union poster is that there is actually no clear scientific reason to stop minke whaling. Even IWC's own scientific committee had not claimed that minke stocks were in danger of extinction. Not surprisingly then, the Japanese see their defeat over whaling as a victory for US environmentalists and a view of the morality of the killing of whales they do not share. Strong emotions have been aroused about the way in which foreign pressure has crushed an ancient industry - indeed the Seaman's Union poster carries a different message in Japanese: "Defend our traditional whaling", and has a picture of a traditional craft with rowers clad in loin-cloths to drive home the point.

US environmentalists have recently tried to ease tension by rewarding cases of Japanese kindness to whales. A baby whale that became entangled in a shore net and ended up still alive at a fish market was recently bought by a group of fifteen Odawara fishermen and returned to the sea. Earth Trust, a US environmental group, then gave them a 20,000 yen reward together with a commendation and a whale sculpture. The fishermen, who had been moved to free the whale because "it looked as though it was shedding tears", will donate the money to African refugees.

The whales may be a lot better off for these developments but the United States may well feel a backlash. The Japanese feel they have been forced to concede and the next issue may be that much harder fought.

David D. Swimbanks 